\title{
Why, When, and How Should the Effect of Marketing Be Measured? A Stakeholder Perspective for Corporate Social Responsibility Metrics
}

\author{
Priya Raghubir, John Roberts, Katherine N. Lemon, and \\ Russell S. Winer
}

\begin{abstract}
This article provides a framework that can be used to design a metrics system for organizations with multiple stakeholders and shows how it can be applied in the area of corporate social responsibility (CSR). The authors propose that the effort to identify, collect, and calibrate metrics is critical for the diffusion of CSR activities across corporations because metrics allow the goals of different stakeholders to be expressed in terms of a single common denominator. The authors propose the AGREE model, which incorporates multiple stakeholders (audiences); multiple value functions (goals); the inputs, commitments, and actions needed to realize the consensus goals (resources); intertemporal returns (effectiveness); and the costs of such actions (efficiency). This approach leads to a set of metrics that can be used to assess the impact of CSR actions on stakeholders beyond the company's customers, collaborators, and competitors to the larger community. The article concludes with an examination of the issues involved in harnessing CSR metrics to evaluate performance and guide future actions.
\end{abstract}

Keywords: corporate social responsibility, marketing metrics, stakeholders

\begin{abstract}
The social responsibility of business is to increase its profits.
\end{abstract} (Friedman 1970)

Holy grail found: Absolute, definite proof CSR pays off. (Kelly 2004)

200 years' worth of work in economics and finance indicate that social welfare is maximized when all firms in an economy maximize total firm value. (Jensen 2002, p. 239)

$7 r$ oday, chief marketing officers (CMOs) are increasingly being scrutinized for the impact of marketing expenditures on firm-level measures, such as profits

Priya Raghubir is Professor of Marketing and Mary C. Jacoby Faculty Fellow, Stern School of Business, New York University (e-mail: raghubir@stern.nyu.edu). John Roberts is Professor of Marketing, Australian National University, and Professor of Marketing, London Business School (e-mail: john.roberts@anu.edu.au). Katherine N. Lemon is Accenture Professor and Professor of Marketing, Carroll School of Management, Boston College (e-mail: kay.lemon@bc.edu). Russell S. Winer is William Joyce Professor and Chair of the Department of Marketing, Stern School of Business, New York University (e-mail: rwiner@stern.nyu.edu). This article was based on the discussions at the Aspen Stakeholders' Conference, 2007. The authors gratefully acknowledge the support of the Aspen Foundation and the comments of the audience. and stock price. The field of metrics has been a top research priority of the Marketing Science Institute (2008) for the past six years. It has also been a critical issue for CMOs, as noted by the CMO Council's senior vice president, Christopher Kenton, who suggests that the two real drivers behind the push for marketing metrics are (1) measuring the value of a business and (2) being able to turn intangibles into value. In particular, he notes, "Beyond the drumbeat of short-term pressures, there are more sustainable advantages to be gained from a solid understand of marketing metrics. Perhaps the most important advantage is the most intangible: the knowledge of what adds value to your company's bottom line" (Kenton 2005). The importance of this topic is underscored by the recent research initiative cosponsored by the Marketing Science Institute and Emory Marketing Institute, "Marketing Meets Wall Street" (see http://www.msi. org/research/index.cfm?id=146 and http://www.emorymi. com/wallstreet.pdf), in which marketing, accounting, and finance academics tested hypotheses that relate marketing to financial outcomes (see also the November 2009 special issue of Journal of Marketing). The market value of a firm as reflected by its stock price links an important set of stakeholders (investors, financial markets) to a key firm objective-shareholder wealth (for a thorough study of this issue, see Srinivasan and Hanssens 2009). 


\section{Importance of Adopting a Stakeholder Orientation}

The prevalent and dominant view in the economics and finance literature defines the shareholder of the firm as the primary stakeholder (Friedman 1970; Jensen 2002). However, a first step toward incorporating externalities is to identify all potential stakeholders and their likely interests. The classical strategic marketing perspective argues that it is necessary to go beyond the company to examine the effects of a company's actions on its customers, channels, and competitors. Within the company, stakeholders include its labor, financial stakeholders (investors and lenders, based on the view of a company as an agency that exists to provide stakeholder value), and management boards. Beyond this view is the larger definition of an external environment that encompasses various publics, such as regulators, the legal system, the government, consumer groups, nonprofit organizations, corroborators (e.g., cobranding partners, endorsers, media), society, the environment, and the economy.

Regardless of whether the need to account for community concerns is due to a moral responsibility of marketing (see Mick 2007) or to it simply being good business practice, insofar as it eventually leads to profitability for the company, an explicit recognition of the intended and unintended consequences of marketing actions on the larger community within which a company operates is increasingly being recognized by marketing academics, corporations, and individuals (e.g., Lemon and Seiders 2005). The need to move beyond the shareholder primacy principle is also reflected in the growing recognition in accounting, finance, and economics that environmental (Nakao et al. 2007), social (including labor [see Backhaus, Stone, and Heiner 2002] and charitable donations [see Navarro 1988; Schwartz 1968]), and governance (Hermalin 2005) value drivers are material to a company's financial performance and investment returns; this is commonly referred to as the ESG (environmental, social, and governance) framework or, more popularly, triple bottom line (Elkington 1998).

To the traditional marketing 3C framework (company, customer, and competition), we now propose the inclusion of a fourth C, the "community," as a key stakeholder. This view echoes the belief that it is time to move beyond the clichéd four Ps (product, price, promotion, and place) tactical framework to include people, partners, and the planet (Bhattacharya and Korschun 2008; Forbus 2007; Mick 2007). Explicitly incorporating a stakeholder orientation leads to the following questions:

-Which stakeholders have a legitimate interest? (A: audience)

-What is that interest? (G: goal)

-What inputs, commitments, and actions are needed to realize the consensus goals? (R: resources)

-How can it be determined whether that interest has been catered to? (E: effectiveness)

-How can it be evaluated whether the use of resources to cater to the goal is optimal? (E: efficiency)

Table 1 provides a list of the measures of effectiveness (or distal outputs) that may have value to the different stakeholders of the firm. We classify these by the audiences (or stakeholders) for whom they are pertinent and the rele- vant goals those stakeholders value. In the remainder of this article, we describe this audience-goal-resourceeffectiveness-efficiency (AGREE) framework in greater detail.

Many of these effectiveness measures are covered in a domain-specific literature. For example, employee stakes are discussed extensively in the organizational behavior and the industrial relations literature (Rosenbloom 2001). Community needs are covered extensively in welfare economics and development economics (Ray 1998). Although specific situations lend themselves to customized lists and more topical measures, what is important in the process of specifying metrics in a given situation is the combination of financial and nonfinancial long-term and short-term consequences for relevant audiences-namely, the stakeholders of a firm.

\section{Corporate Social Responsibility as an Example to Illustrate the Importance of a Stakeholder Orientation}

The need for firms to adopt a stakeholder orientation to design and communicate their marketing activities is arguably most pertinent when their corporate social responsibility (CSR) initiatives are considered. Firms use CSR initiatives to build and strengthen relationships with multiple stakeholder groups beyond the customer, suppliers, channel members, and competitors to include investors, employees, boards of directors, society, regulators, media, and financial markets. Corporate social responsibility represents a context in which there are a large number of different stakeholders with different, potentially conflicting goals. As such, it is a useful context in which to examine the potential role of metrics in comparing, integrating, and reconciling the goals of different stakeholders. This article focuses on CSR activities and the metrics that can be used to assess their effectiveness to illustrate the advantage of a firm adopting a stakeholder orientation.

Two reasons have been suggested for companies engaging in CSR initiatives: CSR as a route to profitability and CSR as an end in itself. In line with the former, company managers may believe that CSR initiatives focusing on intermediate nonfinancial objectives that have a short-term negative cash flow may have a positive long-term effect on value. Routes through which CSR can increase firm value are by facilitating the design of innovative products (Kanter 1999), attracting labor (Backhaus, Stone, and Heiner 2002), attracting and retaining customers (Luo and Bhattacharya 2006; Sen and Bhattacharya 2001), reducing manufacturing costs (Hart and Ahuja 1996), and providing reputation insurance in a crisis (Peloza 2006; Schnietz and Epstein 2005).

Alternatively, or in addition, the mere conduct of CSR activities, such as pollution disclosures in annual financial statements (Freedman and Jaggi 1982; Hamilton 1995), and, previously, divestment in South Africa (Grossman and Sharpe 1986), can be a positive signal for regulators (Blacconiere and Patten 1994; Goyal 2006) and investors (Belkaoui 1976; Belkaoui and Karpik 1989; Ingram 1978). This positive signal can generate financial returns (Harjoto and Jo 2007; Hamilton, Jo, and Statman 1993), both in the 
Table 1. Translating Stakeholder Audience Goals into Effectiveness Metrics: The AGREE Framework

\begin{tabular}{|c|c|c|}
\hline Audience for CSR & Goal Hierarchy & Effectiveness Metrics \\
\hline \multicolumn{3}{|c|}{ Classic Strategic Marketing Stakeholders } \\
\hline Customer & $\begin{array}{l}\text {-Satisfaction/delight } \\
\text {-Availability (supply) } \\
\text { - Value for money } \\
\text {-Quality of life } \\
\text {-Ego fulfillment } \\
\text {-Self-actualization }\end{array}$ & $\begin{array}{l}\text {-Satisfaction level } \\
\text {-Lifetime value } \\
\text {-Sales, brand equity } \\
\text { - Affective responses } \\
\text {-Goals/achievement } \\
\text {-Value functions }\end{array}$ \\
\hline $\begin{array}{l}\text { Suppliers, channel, and } \\
\text { other collaborators }\end{array}$ & $\begin{array}{l}\text {-Satisfaction/delight } \\
\text {-Availability } \\
\text {-Value for money }\end{array}$ & $\begin{array}{l}\text {-Satisfaction } \\
\text {-Lifetime value } \\
\text {-Margins, sales }\end{array}$ \\
\hline Competitors (industry) & $\begin{array}{l}\text { •Industry growth } \\
\text {-Industry profitability }\end{array}$ & $\begin{array}{l}\text {-Market share } \\
\text {-Penetration rates } \\
\text {-Access }\end{array}$ \\
\hline Company & •Profitable, growing, stable & $\begin{array}{l}\text {-Brand value, profitability, customer base, return on } \\
\text { assets/investments, sales revenue }\end{array}$ \\
\hline
\end{tabular}

Other Stakeholders Internal to the Company

\begin{tabular}{|c|c|c|}
\hline Investors & $\begin{array}{l}\text {-Maximize returns, minimize risks (across } \\
\text { time and across portfolio) }\end{array}$ & $\begin{array}{l}\text {-Financial returns, return on investment, abnormal returns } \\
\text {-Stock price: mean, trend, variance }\end{array}$ \\
\hline Employees & $\begin{array}{l}\text {-Salaries and other remuneration } \\
\text {-Achievement, affiliation, social, and } \\
\text { psychological needs }\end{array}$ & $\begin{array}{l}\text { - Acceptance/retention/turnover rates } \\
\text { - Length of term/average cost per employee } \\
\text {-Satisfaction, quality of life, performance }\end{array}$ \\
\hline $\begin{array}{l}\text { Board of directors, } \\
\text { internal governance, } \\
\text { and management }\end{array}$ & $\begin{array}{l}\text { - Confidence/reassurance } \\
\text { •Power, ego, ease of justification }\end{array}$ & $\begin{array}{l}\text {-Formal evaluations } \\
\text { •External/internal audits }\end{array}$ \\
\hline Personal/individual & $\begin{array}{l}\text {-Maximize positive emotions, minimize } \\
\text { negative emotions }\end{array}$ & -Incidence and extent of physical/mental illness \\
\hline \multicolumn{3}{|c|}{ External Stakeholders: The Community } \\
\hline Society & $\begin{array}{l}\text {-Educated, healthy, wealthy, happy, stable, } \\
\text { cohesive community }\end{array}$ & $\begin{array}{l}\text {-Quality-of-life indicators: physiological (health), } \\
\text { economic, educational, social, psychological } \\
\text {-Examples: percentage of population affected, life } \\
\text { expectancy, literacy rates, income/nutrition per capita, } \\
\text { disease incidence rates, birth/death rate by age }\end{array}$ \\
\hline Environment & -Sustainable & $\begin{array}{l}\text {-Sustainability, improvement in indexes, pollution and } \\
\text { toxicity levels (water, air, other) }\end{array}$ \\
\hline $\begin{array}{l}\text { Regulators, auditors, } \\
\text { nongovernmental } \\
\text { organizations }\end{array}$ & $\begin{array}{l}\text {-Ensuring compliance with existing } \\
\text { regulations and identifying new } \\
\text { regulations to keep consumer welfare } \\
\text { interests in line with corporate } \\
\text { profitability goals }\end{array}$ & -Credit from regulators, inclusion in CSR indexes \\
\hline Media & $\begin{array}{l}\text {-Providing accurate, timely, and } \\
\text { newsworthy information to the public }\end{array}$ & -Quantity and quality of press impact \\
\hline Financial markets & -Stability, growth, and profitability & $\begin{array}{l}\text {-Rates of return, volatility, turnover, and liquidity over } \\
\text { time }\end{array}$ \\
\hline Economy & -Stability, growth, and profitability & $\begin{array}{l}\text { - Gross domestic product/gross national product, per } \\
\text { capita, and overall; debt ratios; foreign exchange } \\
\text { reserves }\end{array}$ \\
\hline
\end{tabular}

United States and overseas (Hill et al. 2007; Knack and Keefer 1997). Conversely, information about company illegalities (Davidson and Worrell 1988; Frooman 1997; Karpoff and Lott 1993; Karpoff, Lott, and Wehrly 2005) and product recalls (Davidson and Worrell 1992; Jarrell and Peltzman 1985) leads to negative financial returns.

Beyond profitability and information signals, stakeholders in large and profitable firms may engage in CSR activi- 
ties simply because they can afford to (Allouche and Laroche 2005; Orlitzky, Schmidt, and Rynes 2003), have more opportunities to (Campbell 2007), and face more pressure from external constituents (e.g., social activists; Spar and La Mure 2003) than smaller or less profitable companies. This would lead to a spurious correlation between firm profitability and CSR activities that does not invoke CSR achieving specific goals of key stakeholders.

A qualitatively different reason espoused for CSR activities is that stakeholders such as company employees, management, and board members are motivated to feel good about themselves (Sandelands 2003) and about the company in which they work by returning part of the wealth they have created back to society because of their extrafinancial values and goals (Frank 2007). This leads to the question whether stakeholders engage in CSR activities because they are virtuous per se (Bragdon and Marlin 1972) or because the CSR activities have downstream benefits. Identifying downstream benefits (and costs) of CSR to a range of stakeholders enables companies to make informed decisions about incorporating the heterogeneity in the goals of different stakeholders into CSR initiatives. However, feedback effects are difficult both to identify and to calibrate, as evidenced by more than a third of a century of research into whether CSR activities add value to the firm, over what period, and through which pathways.

\section{The Role of Metrics to Identify, Compare, and Integrate Stakeholders' Goals}

This article argues that the effort to identify, collect, and calibrate metrics is critical for the diffusion of CSR activities across corporations because metrics allow the goals of different audiences to be expressed in terms of a single common denominator. Since Bragdon and Marlin (1972) published the first examination of whether pollution was profitable, the question of why companies "do good" and whether they "do well" in the process continues to be a matter of academic debate (in economics, see Friedman 1970; Knack and Keefer 1997; Sauer 1997; Van de Velde, Vermeir, and Corten 2005; in finance, see Hamilton, Jo, and Statman 1993; Shank, Manullang, and Hill 2005; Statman 2000; in accounting, see Barth and McNichols 1995; Blacconiere and Patten 1994; Chen and Metcalf 1980; in marketing, see Luo and Bhattacharya 2006; Sen and Bhattacharya 2001; in management, see Alexander and Buchholz 1978; Arlow and Gannon 1982; Margolis and Walsh 2003; Walsh 2005; in business ethics, see Hill et al. 2007; Vershoor 1988; and in corporate law, see Avi-Yonah 2005; Morrissey 1989; Wells 2002). After 36 years, 167 studies, and 16 reviews of the relationship between CSR and financial performance, the answer to the debate about whether CSR is profitable is unambiguously clear: "It depends" (Margolis, Elfenbein, and Walsh 2007).

The question whether CSR activities pay off is a function of what is measured, how the stakeholders of a firm who constitute the audience for a CSR initiative are defined, the goals of these audiences, the effectiveness of the initiative to achieve the audience's goals, and the efficiency in the use of the resources to achieve those goals-that is, metrics. The thesis of this article is that the question whether a com- pany can "do well" by "doing good" is a function of the metrics used to measure what different audiences' goals are and how effectively and efficiently they have been achieved. Metrics translate goals into measurable inputs and outputs, allowing for an explicit examination of the effectives of achieving goals and the efficiency of the resources deployed to do so. They are used to evaluate and compare the answers to business questions in every traditional functional domain of an organization. They range from dollar metrics (in finance) to throughput (in operations) to employee satisfaction (in management). Common marketing metrics include sales revenue, profitability, penetration, advertising reach and recall, customer satisfaction, and brand loyalty. The primary function of metrics is to calibrate, evaluate, and justify decisions that have been executed (performance measurement) or are being considered (planning and option evaluation). In this sense, metrics are both backward and forward looking. The calibration function of metrics involves converting distinct decision alternatives that are initially incomparable into a set of consequences scaled on desirability so that it is possible to evaluate and contrast different alternatives. The evaluation function of metrics involves measuring the performance of different options given their required inputs against one another and external benchmarks, including future goals, past performance, comparison with other organizations, and the status quo, allowing for an ordering of alternatives in terms of agreed-on organizational goals. The justification function allows people in organizations with different points of view to argue a case for or against a course of action using a common set of terms and definitions. This function of metrics is particularly important when a course of action is relatively new, when it is without precedent, and when there are dissenting points of view.

Corporate social responsibility metrics can identify, broaden, and increase the efficiency and effectiveness trade-offs of different stakeholders' goals associated with different marketing activities. Beyond this, they can establish the business legitimacy of CSR (Bhattacharya and Sen 2004; Sen, Bhattacharya, and Korschun 2006). Penetration of CSR-related activities can be thought of as analogous to the manner in which innovations diffuse over time (i.e., a traditional product life cycle). We argue that a key function of metrics is to take an idea from the stage when innovators and early adopters buy into the idea and understand its efficacy across the chasm to the early majority. We suggest that the area of CSR in marketing - specifically, the need to incorporate the goals of multiple stakeholders in a marketing calculus - is a relatively recent one, and for this idea to become commonplace, metrics that can be used to inform, evaluate, and justify a CSR decision must be defined and accepted. Without metrics, companies that believe in CSR will continue to do so (e.g., the Body Shop), without the idea becoming mainstream across corporations. Indeed, changing corporate imperatives, new ownership, or a tougher financial climate may lead to disadoption. However, with metrics, it is possible that firms that doubt the rationale for engaging in CSR-related activities or have been delaying their decision to engage in them will be more likely to enter the field because the benefits will be more demonstrable. Thus, the role of metrics in the life cycle of 
CSR would be a persuasion function to help CSR-related activities "cross the chasm" (Moore 1999). Metrics increase the ease of observing and communicating the benefits of an idea, allow for a reduction in the complexity of decision making by using a measurable common denominator, legitimize the process, and provide the comfort of reducing risk by showing the benefits of a course of action on agreed-on goals. All these benefits aid in the diffusion of innovations and should aid the growth of CSR beyond the innovators and early adopters. Metrics can also ensure that disadoption does not occur. Without metrics to calibrate its effects, in good times, CSR may be adopted as either an act of faith or an act of charity, but with metrics, CSR can become an element of mainstream strategy.

We now develop a model of how to balance different objective functions across stakeholders over time. We refer to the audience of the CSR activity, the goals of the stakeholders, the resources used to achieve consensus goals, the effectiveness with which the stakeholders goals are realized, and the efficiency with which the resources deployed are able to do so as the AGREE model.

\section{A Company's Stakeholders: Audience}

Who is the audience for CSR activity? Is it the investor, as Friedman (1970) argues, or is it the customer, as Sen and Bhattacharya (2001) suggest? Is it the job seeker or employee, as Backhaus, Stone, and Heiner (2002) argue, or could it be a channel member, legislator, regulator, or consumer welfare group? Beyond these immediate stakeholders of a firm, can the audience for CSR be the community itself, with virtue being its own reward (Bragdon and Marlin 1972), or is the audience the board of directors of the firm?

What these questions suggest is that CSR must take into account the objectives, values, and preferences of all members of the community who have an interest in the actions of the firm (i.e., the stakeholders), accounting for externalities that a myopic, profit-maximizing firm might otherwise neglect (Carroll 1979, 1991, 1999; Elkington 1994). The question then arises, How does a firm that practices CSR behave differently from one that does not? We illustrate this issue in Figure 1. Figure 1, Panel A, shows the classical market-based firm that sells goods and services to a customer in a profit-maximizing way by optimizing the revenue it gains given the costs it incurs (or minimizing the costs required to obtain certain revenue). Figure 1, Panel B, considers other potential stakeholders, such as suppliers, corroborators, the environment, channels, various publics, and the government. With Figure 1, Panel B, we can classify the types of nonglobal optimality that may occur: acts of commission and acts of omission. Acts of commission occur when organizations do things that are inappropriate (e.g., Nike's use of Asian sweatshops). ${ }^{1}$ Acts of omission occur when organizations fail to do things that they should (e.g., not developing a microfinance program). When the externalities represented by the dashed lines are strong, marketers' actions are most likely to be different depending

\footnotetext{
${ }^{1}$ See http://www.globalexchange.org/campaigns/sweatshops/nike/.
}

on whether they are in an environment represented by Panel A or Panel B in Figure 1.

Metrics make it possible to analyze how the world would be different if the interests of the other stakeholders were accounted for, because metrics allow for comparability across different dimensions that are salient to various stakeholders (i.e., address their goal achievement). Metrics also allow for an examination of outcomes across different periods - a relevant issue because people's intertemporal discount rates are high, with long-term benefits being undervalued relative to short-term gains (Frederick, Loewenstein, and O'Donoghue 2002). Table 2 outlines examples of the four types of nonglobal optimality: shortterm and long-term costs and benefits of acts of commission and omission.

\section{Understanding Stakeholder Utility (Goals)}

Returning to the costs and benefits of ignoring externalities (Table 2), we need to assess CSR metrics that cover both short-term and long-term effects (Shank, Manullang, and Hill 2005). This implies a time-dependent model of CSR effects. Furthermore, given the range of stakeholders with different value functions, a secondary challenge is to assess the effect of an action on the utility of different stakeholders and then to propose a calculus to combine these (Carroll 1979, 1999). We discuss these issues next.

\section{Figure 1. Contrast of Traditional and Extended Views of} Marketing Activity and Firm Performance

A: Classical Economic View of a Marketing Transaction

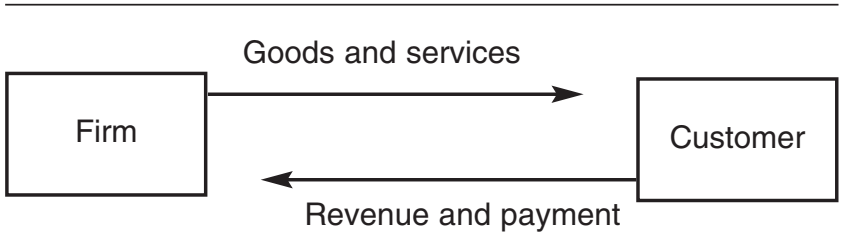

B: Extended Stakeholder View of a Marketing Transaction

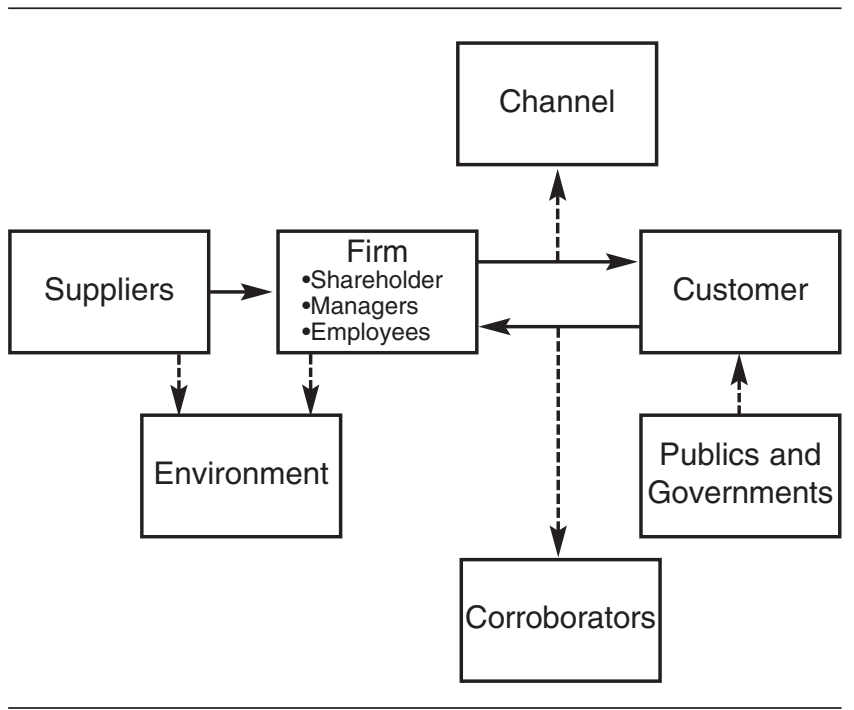


Table 2. Potential Misallocation Decisions (Ignoring Figure 1, Panel B, Externalities)

\begin{tabular}{|c|c|c|}
\hline & Short-Term Cross-Sectional & Long-Term Intertemporal \\
\hline \multirow[t]{4}{*}{ Acts of commission } & $\begin{array}{l}\text { Externalities are not identified, leading to } \\
\text { high-net-cost activities. }\end{array}$ & $\begin{array}{l}\text { High discount rates on future costs encourage projects } \\
\text { with future problems. }\end{array}$ \\
\hline & •Example: Nike's use of Asian sweat shops. & $\begin{array}{l}\text {-Example: Companies' continued use of technologies that } \\
\text { lead to high pollution levels. }\end{array}$ \\
\hline & $\begin{array}{l}\text { If Nike had identified labor and society as } \\
\text { stakeholders, it could have explicitly examined the } \\
\text { implications of the release of this information on } \\
\text { other stakeholders, such as consumers, regulators, } \\
\text { and financial markets. }\end{array}$ & $\begin{array}{l}\text { If companies account for and measure the positive } \\
\text { benefits of their sustainable technologies on the } \\
\text { environment, they can explicitly examine the effect of } \\
\text { this information on their other stakeholders (e.g., } \\
\text { customers, regulators, markets). }\end{array}$ \\
\hline & $\begin{array}{l}\text {-Typical metric: } \mathrm{CO}_{2} \text { emissions associated with an } \\
\text { airline ticket. }\end{array}$ & $\begin{array}{l}\text {-Typical metric: Future crime rates associated with a } \\
\text { child support scheme. }\end{array}$ \\
\hline \multirow[t]{4}{*}{ Acts of omission } & $\begin{array}{l}\text { Lack of market mechanisms lead to valuable } \\
\text { projects not being funded. }\end{array}$ & $\begin{array}{l}\text { High discount rates on future benefits penalize valuable } \\
\text { forward projects. }\end{array}$ \\
\hline & $\begin{array}{l}\text {-Example: Before Grameen Bank, other bands did } \\
\text { not undertake microfinancing because they were } \\
\text { unsure of the risk-reward payoffs. }\end{array}$ & $\begin{array}{l}\text {-Example: Companies not engaging in Project Red. In } \\
\text { contrast, Gap has increased the sourcing of products in } \\
\text { its Project Red campaign, hoping for economic trickle- } \\
\text { down effects to reduce the spread of AIDS and thus } \\
\text { reduce the turnover in factories. }\end{array}$ \\
\hline & $\begin{array}{l}\text { If other banks had identified society as a } \\
\text { stakeholder, they could have examined the } \\
\text { profitability of entering poorer segments of society. }\end{array}$ & $\begin{array}{l}\text { By recognizing that its labor and the society in which it } \\
\text { resides is a stakeholder, Gap is able to develop a } \\
\text { cohesive project that is win-win for customers, labor, } \\
\text { and society. }\end{array}$ \\
\hline & $\begin{array}{l}\text {-Typical metric: Aluminum recycling rates as a } \\
\text { result of failing to have a soda can deposit scheme. }\end{array}$ & $\begin{array}{l}\text {-Typical metric: Future marine biodiversity as a result of } \\
\text { failure to launch biodegradable detergents. }\end{array}$ \\
\hline
\end{tabular}

To develop a model of how stakeholder i might evaluate the outcome of marketing activity $\mathrm{j}$ on a range of relevant dimensions $\mathrm{k}, \mathrm{y}_{\mathrm{ijk}}$, we consider the objective function of the stakeholder. That is, we work out the weight that the stakeholder gives to each dimension, $\mathrm{w}_{\mathrm{ik}}$, and use a standard multiattribute utility model to determine the utility (or disutility), $\mathrm{U}_{\mathrm{ij}}$, to be gained from the activity from stakeholder i's perspective (we could also include nonlinearities and interactions):

(1)

$$
\mathrm{U}_{\mathrm{ij}}=\sum_{\mathrm{k}} \mathrm{w}_{\mathrm{ik}} \times \mathrm{y}_{\mathrm{ijk}} \text {. }
$$

We can incorporate time in this formulation by recognizing that net benefits (or net costs) of the outcome on dimension $\mathrm{k}$ may accrue over time, so that $\mathrm{y}_{\mathrm{ijk}}$ will be the sum of benefits (costs) over time, $y_{i j k t}$, suitably adjusted by the discount rate, $r_{i k}$ (which will be specific to individual stakeholders):

$$
\mathrm{y}_{\mathrm{ijk}}=\sum_{1}^{\mathrm{T}} \frac{\mathrm{y}_{\mathrm{ijkt}}}{\left(1+\mathrm{r}_{\mathrm{ik}}\right)^{\mathrm{t}}} .
$$

We are now in a position to consider how the agendas of different stakeholders can be combined. The most obvious approach is in a linear way, assigning different weights to each stakeholder $\mathrm{i}, \lambda_{\mathrm{i}}$. As such, total public welfare, $U_{\mathrm{j}}$, is given by the sum of each stakeholder's utility, weighted by the strength of the claim of that stakeholder:

$$
\mathrm{U}_{\mathrm{j}}=\sum_{\mathrm{i}} \lambda_{\mathrm{i}} \times \mathrm{U}_{\mathrm{ij}}=\sum_{\mathrm{i}} \lambda_{\mathrm{i}} \sum_{\mathrm{k}} \mathrm{w}_{\mathrm{ik}} \times \mathrm{y}_{\mathrm{ijk}}
$$

More complex models are clearly possible. For example, a firm that wants only to avoid breaking the law would implicitly be using a compound conjunctive model. Another way that this basic model could be extended is by incorporating uncertainty. For example, a dominant player in one market might consider it appropriate to bundle products, implicitly forcing the consumers of its major product to forgo choice of other complements and denying market access to its competitors. However, in a more complex model, the dominant player might not undertake this behavior because it factors in the chances of a regulator taking action against it and creating an even less attractive market.

\section{Achieving Goals Across Stakeholders: Resources, Effectiveness, and Efficiency}

As with many models in marketing, it is useful to understand the relationship between specific marketing actions (the "inputs") and the results of those actions (the "outputs"). Specifically, how can the pathways be traced from activities (resources) to the outcomes that lead to the achievement or diminution of stakeholder goals to measure how well and how cost efficiently audiences' goals are realized. 


\section{Resources (Inputs)}

In the absence of metrics that define measurable output, decision makers may use the size of input to measure the extent of CSR involvement of a company across time and compared with other companies. Although input levels are a reasonable starting point, the ability to translate the input into a measurable output is important to inform, evaluate, and justify decisions (and reassure decision makers). Inputs can be measured using at least three metrics of scarce company resources: money, people, and time. For example, commonly used measures of corporate social performance include charitable contributions and philanthropic acts (Navarro 1988; Schwartz 1968), revealed misdeeds (Karpoff and Lott 1993), transparency of reporting (Belkaoui and Karpik 1989), and corporate policies and statements of ethics (Vershoor 1998) - all of which are firm inputs. Beyond inputs such as money and productive resources from firms, other resources that may be required for CSR include incentives (and punishments) from governments, infrastructure and engagement from communities, and attitudes and behaviors from customers. Having decided on the necessary resources, a firm then needs to examine how well its has achieved the goals it set out to achieve (effectiveness) and how cost effectively it did so (efficiency); that is, the firm must define the types of outputs desired and relate the resources used to the outputs that the resources were intended to achieve.

\section{Outputs}

Outputs can be measured quantitatively or qualitatively and subjectively or objectively, they can be intended or unintended, they can be short term or long term, and they can be measured in terms of the different value functions stakeholders hold. The scope of this article is restricted to the assessment of quantitative metrics, though we acknowledge the role of qualitative assessment in decision making because of its ability to capture human emotions and life aspects more holistically and present them more engagingly than numbers. Subjective outputs include self-reports and observer reports (e.g., ratings from the Fortune 500 database of most admired companies) of a company's performance, whereas objective outputs are based on third-party audits (e.g., Superfund site liabilities in Harper and Adams 1996) and membership into specific categories (e.g., the Kinder Lydenberg Domini Index, which evaluates companies on eight dimensions ${ }^{2}$ ).

Intended consequences refer to the extent to which a CSR effort achieved its specific goal (e.g., reduced the percentage of child labor). Unintended consequences explore the ramifications of that goal for other desirable consequences (e.g., increased percentage of children attending school), as well as potential undesirable consequences (e.g., reduced income levels, higher levels of crime, higher rates of unemployment). These unintended consequences may affect multiple stakeholders.

Outputs can further be understood as short term and long term, such that short-term outputs can lead to long-term, trickle-down effects. Metrics need to allow for comparabil-

\footnotetext{
2See http://www.kld.com/indexes/index.html.
}

ity between long-term, trickle-down effects and more current, short-term consequences, as related to the current period of decision making.

Finally, outputs can be domain specific (e.g., environment, social, labor, health, education) or based on a common measure (financial, accounting, or marketing). For example, if improving the environment is an end in and of itself, measures that incorporate the level of emissions and toxicity would be appropriate distal outputs, but if improving the environment is a route through which the company wants to generate a positive reputation, the distal output could be brand equity, or stock price. Thus, researchers are encouraged to examine the effects of CSR investments on multiple, diverse outcomes, such as market share, price premium, loyalty, and customer lifetime value. For example, Bhattacharya and Sen (2004) develop a model of consumer response to CSR that investigates the relationships between CSR initiatives and price premium, customer loyalty, and word of mouth. In other research, Rust, Lemon, and Zeithaml (2004) examine the relationship between investments in corporate citizenship activities and customer lifetime value and find that, for some industries, such investments have a significant, positive effect on customer lifetime value.

The AGREE approach we put forth in this article allows for a subtler and more multifaceted view of the complexity of changing communities than a simplistic single-construct approach. It also requires the community and the people who are (or may be) affected by a company's CSR activities to be partners in identifying the short-term and longterm consequences of every course of action, both positive and negative. Beyond the identification of consequences, stakeholders are essential in defining the stakes that are relevant for them (or spelling out their goals) because these may differ across groups of stakeholders and within subgroups of stakeholders. Although explicit recognition of stakes and consequences of action is necessary, this does not imply that companies should only engage in stakes that are most relevant to their most immediate stakeholders. A company's choice of which action to engage in is contingent on balancing the stakes across different stakeholders (of which one would be the community being affected), each of which may have different objectives in the short and long term. For example, increasing health benefits to employees would increase employee satisfaction, but this may come at the expense of short-term profitability. Similarly, sourcing products using unethical means could reduce product price and increase levels of customer satisfaction, but this may come at the cost of harming the society in which the products are sourced (i.e., an external stakeholder).

\section{Gap: Project Red-An Example}

Gap Inc. is interested in reducing the spread of AIDS in the communities from which it sources its product in Africa (Silten 2007). This is consistent with the company's objectives for several reasons, including its philosophy that "Trade, Not Aid" is the route through which sustainable change is effected and its tangible need to reduce the turnover in factories, which employ labor from the AIDS- 
stricken communities. Despite recognizing the need to reduce the spread of AIDS, the people in the community may have other goals that they believe would improve their lives to a greater extent and in a more immediate way. These could range from safe water technologies to direct subsidies for health, education, shelter, and food. Examining the consequences (positive or negative) of an AIDSrelated initiative on these other community goals should be part of Gap's CSR metric. Identifying what the company should do would be based on incorporating the objective function of this group of stakeholders with other stakeholders, such as labor, employees, customers, and shareholders. In other words, stakeholders need to identify their goals, and a company can choose a course of action by balancing competing stakes across stakeholders.

\section{Operationalizing CSR Marketing Metrics}

The operationalization of a system to gather CSR metrics requires specifying sources of information, determining levels of aggregation and timing, and validating information sources. To establish causality, a CSR action should precede an outcome variable for a sample that was matched in terms of exogenous variables and/or randomly assigned to a CSR condition, with objective sources of input and output information, at a disaggregated level, and across domains. Needless to say, such a situation does not exist.

The next best methodological solution is to execute controlled field experiments in which a variable (e.g., a CSR activity) can be manipulated across different companies and an outcome (e.g., profits) can then be observed. However, this is also rarely achievable because of the difficulty of assigning companies at random to a CSR condition and isolating the effect of a single CSR variable.

The closest thing to a field experiment is an "event study." In financial applications of this methodology, the price of a company is observed before and after a specific event or announcement (e.g., a scandal, a new product). Because the company serves as its own control, the risk of confounding variables (e.g., company size, industry, risk profile) is reduced, and the timing of the exogenous shock allows for an isolation of the mechanism by which a firm's actions affect its performance (e.g., in relation to the stock market). In financial event studies, researchers create a dependent variable called "excess returns," which is the ratio of a firm's observed stock price return to what would be expected as a baseline determined by past stock prices under an assumed efficient-market model. An "event" is defined as a discrete change observed in the firm's behavior, such as the adoption of a new branding strategy, an advertising campaign, or an investment in an energyconserving manufacturing facility. Examples of these approaches are studies that examine product recalls (Davidson and Worrell 1992; Jarrell and Peltzman 1985), the announcement of the Toxics Release Inventory data (Hamilton 1995; Konar and Cohen 2001), and firm disclosures about socially responsible actions (Ingram 1978). Dependent variables for CSR could be broadened to include other nonfinancial measures, such as those listed in Table 1.

Applying these methods is not without problems. Because of the scarcity of data points surrounding a specific discrete event, researchers have relied on a cross-sectional correlation analysis to examine whether companies that are rated higher in terms of CSR metrics perform better using traditional financial and accounting performance metrics (Hamilton, Jo, and Statman 1993; Statman 2000). However, these analyses have been critiqued because of confounding variables that can lead to misspecification (McWilliams and Siegel 2001), suggesting the need for an instrument variable approach (Harjoto and Jo 2007) or matched pair analyses (Kreander et al. 2005). Applying this methodology to the marketing literature, Luo and Bhattacharya (2006) use a variety of secondary sources and measures to determine the relationship between a firm's CSR activities and its stock price. The positive relationship the authors find is an important step in validating corporate CSR expenditures on goals other than "doing good." A similar approach involves examining the portfolio returns of the Domini 400 Social Index over time (certified socially responsible funds) versus other indexes that are not CSR certified (Luck and Pilotte 1993). Therefore, it is possible to develop relationships between CSR efforts and different CSR metrics using existing methods. The steps involved in terms of the AGREE framework are as follows:

1. Quantitatively assessing inputs. (R: assessing resources)

2. Quantitatively assessing outputs ... (G: identifying goals)

a. For the value functions of each of the stakeholders involved. (A: audiences)

b. That are intended or unintended; positive, negative, or neutral in terms of stakeholder goals; and in the short term and long term.

3. Determining the relationship between inputs and outputs, over time, and across the range of metrics that address the roles of different stakeholders. (E: mapping efficiency in resource use)

4. Expressing outcomes in current value terms and aggregating across dimensions, weighted by the importance of different stakeholders. (E: examining the effectiveness of the initiative)

\section{Complicating Issues and Next Steps}

Up to this point, we have set out an approach toward CSR metrics that incorporates multiple stakeholders, multiple value functions, and intertemporal returns and costs. It is important to recognize that this approach is not without difficulties and complexities. Although we believe that recent developments in models that link marketing inputs to marketing outcomes are encouraging, there is clearly more work to be done. We now discuss some of these challenges and describe potential next steps.

\section{Balancing Competing and Sometimes Incompatible Objectives}

Although Equation 3 and its more complex variants provide a method of combining the interests of different stakeholders, even in its most simple form, different groups will have different perceptions of the appropriateness of the weight that should be attached to different stakes, $\lambda_{i}$. A public manifestation of this occurred when protestors demonstrated against firms that invested in South Africa during the Apartheid era and when there were attacks on Starbucks 
stores during the 1999 World Trade Organization Seattle riots. ${ }^{3}$ Though potentially complex, CSR metrics and the analysis that accompanies them provide a framework within which to discuss stakeholder trade-offs. To achieve this, a reasonable benchmark is a system that improves equity and transparency, allows trade-offs to be explicit, and identifies improvements in effectiveness and efficiency.

\section{The Credibility of CSR and the Metrics That Underpin It}

As with many other activities, CSR is subject to the freerider problem. Firms "going through the motions" or, in other words, seeking the benefits but not fundamentally embracing the activities may dilute the goodwill created by socially aware and responsive organizations. In the area of environmental CSR, this has been termed "greenwashing." An important role of metrics is for companies systematically engaging in CSR-related activities to be able to differentiate themselves from others that may claim to do so by way of sporadic and superficial efforts. A concern among practitioners going forward is that the CSR "brand name" may be misused, leading to consumer skepticism, with a potential backlash against not only the companies engaging in greenwashing but also CSR itself and the companies that genuinely practice it. ${ }^{4}$ For example, in the United States, legislation is being considered to regulate embedded giving, the fund-raising practice in which firms bundle a gift to charity into an everyday purchase (Strom 2007). Programs that offer to donate a small percentage of every purchase to a specific charity represent one form of embedded giving. Currently, firms are not required to disclose what percentage of the purchase will be donated to charity. Public accountability of CSR claims would help reduce any such backlash from consumer skepticism. Such accountability is possible only in the presence of well-defined metrics. Trusted third parties, such as fair-trade organizations, are already springing up to fulfill this role. An example of this is the Global Reporting Initiative (GRI), which encourages firms to report on their economic, environmental, and social performance in the manner they are accustomed to doing for their financial performance. ${ }^{5}$ The GRI provides firms a framework and guidelines for disclosing information about their sustainability. Although this is a good start, the earth is only one of a firm's many stakeholders. The approach we present herein goes beyond GRI reporting by suggesting that firms should incorporate the goals of a variety of other stakeholders. Thus, audits using commonly accepted metrics, such as those in the GRI guidelines, would be an effective mechanism to prevent "cheap talk," to ensure authenticity, and to establish transparency of CSR initiatives.

\section{The Setting of Standards}

When we try to understand the effect of CSR initiatives on a broader set of stakeholders, the notion of standards and benchmarks becomes problematic. Who is to decide what

\footnotetext{
${ }^{3}$ See http://news.bbc.co.uk/2/hi/americas/547581.stm.

4These concerns have been voiced by Pamela Forbus (2007), vice president of consumer strategy and insights at Frito-Lay, and Bobbi Silten (2007), chief foundation officer at Gap Inc.

5See http://www.globalreporting.org/AboutGRI/.
}

the standards should be for the influence of CSR initiatives? Should the effects of such initiatives or approaches be measured in the short run or the long run? Should measures be taken for a specific constituency or for all stakeholders that might be influenced? There are some situations in which it is simple to identify whether an initiative has had net positive or negative effects. However, beyond these clear-cut acts of commission or omission (be they negative or positive), it becomes a thorny issue that needs to be addressed as CSR matures through its product life cycle. We argue that reliable and comprehensive CSR metrics will provide the foundation for an informed debate on these issues (though they cannot provide the resolution).

\section{Intertemporal Discount Rates: What Matters, When, and to Whom?}

As we briefly noted previously, another critical issue is intertemporal considerations. We know that it is difficult for individuals and organizations to evaluate potential future outcomes accurately, and it is even more difficult for people to sacrifice short-term benefits for long-term benefits. To exacerbate the problem, the capital and reward structures of most firms are focused on short-term results. In terms of CSR metrics, this suggests that firms are more likely to consider (and more heavily weigh) short-term effects of marketing and CSR initiatives relative to longterm ones. How does a short-term orientation (in terms of marketing actions, outcomes, and metrics) influence a firm's understanding of and focus on its broader stakeholders? For example, if a firm considers only the short-term effects of a marketing strategy/campaign (in terms of response, increase in market share, lift, and increased shortterm awareness), does this lead the firm to be less likely to consider the effects of its actions on its customers and other stakeholders in the long run (customer lifetime value, health issues, environment, and social issues)?

It is crucial to develop a set of CSR metrics that cover the temporal spectrum, capturing the effects of CSR in the short, medium, and long run and across multiple stakeholder groups. If such metrics can be identified, they may be able to reduce conflicts between stakeholder groups, recognizing that distinct value functions (with different time frames) may exist and enabling discussions and comparisons across these value functions. Explicit measures of the projected trajectory of marketing and consumption activities and their outcomes will enable an explicit discussion of otherwise implicit trade-offs between current and future generations.

\section{Future Research}

It has been exciting to watch the growth in interest in CSR by the marketing community over the past $10-15$ years. As Carroll (1999) notes, over the past decade, CSR as a field has been moving beyond definitions and toward measurement and implementation. This article's goal has been to take a next step in that direction. It is time for marketing to embrace the complexities of CSR metrics. The conceptual underpinnings of CSR in marketing are now better developed, understood, and accepted. Furthermore, there have been significant advances in the area of marketing metrics, 
especially in linking marketing inputs to outputs. Finally, there is continued interest in the value of CSR to firms and the importance of sustainability.

Together, these three developments make it possible and appropriate to develop, test, and validate CSR metrics. The charge for future research is to identify a range of metrics that companies can use to measure the impact of their actions and nonactions on a range of stakeholders. The measures in the last column of Table 1 provide a starting point toward this. However, future research must examine how well these measures are able to tap into the extent to which stakeholder goals are satisfied (effectiveness criterion), how costly they are to collect, and how persuasive they are in making a case for a marketing action. We hope that our process of understanding different stakeholders and translating their goals into specific measurable metrics provides a framework that can move the field forward.

\section{References}

Alexander, Gordon J. and Rogene A. Buchholz (1978), “Corporate Social Performance and Stock Market Performance," Academy of Management Journal, 21 (3), 479-86.

Allouche, Jose and Patrice Laroche (2005), “A Meta-Analytical Investigation of the Relationship Between Corporate Social and Financial Performance," Revue de Gestion des Resources Humaines, 57, 18-41.

Arlow, Peter and Martin J. Gannon (1982), "Social Responsiveness, Corporate Structure, and Economic Performance," Academy of Management Review, 7 (2), 235-41.

Avi-Yonah, Reuven S. (2005), "The Cyclical Transformations of the Corporate Form: A Historical Perspective on Corporate Social Responsibility," Delaware Journal of Corporate Law, 30 (3), 767-818.

Backhaus, Kristin B., Brett A. Stone, and Karl Heiner (2002), "Exploring the Relationship Between Corporate Social Performance and Employer Attractiveness," Business and Society, 41 (3), 292-318.

Barth, Mary E. and Maureen F. McNichols (1995), "Estimation and Market Valuation of Environmental Liabilities Relating to Superfund Sites," Journal of Accounting Research, 32 (3), 177-209.

Belkaoui, Ahmed (1976), "The Impact of the Disclosure of the Environmental Effects of Organizational Behavior on the Market," Financial Management, 5 (4), 26-31.

and Philip G. Karpik (1989), "Determinants of the Corporate Decision to Disclose Social Information," Accounting, Auditing and Accountability Journal, 2 (1), 36-51.

Bhattacharya, C.B. and Daniel Korschun (2008), "Stakeholder Marketing: Beyond the Four Ps and the Customer," Journal of Public Policy \& Marketing, 27 (Spring), 113-16.

— and Sankar Sen (2004), "Doing Better at Doing Good: When, Why, and How Consumers Respond to Corporate Social Initiatives," California Management Review, 47 (1), 9-24.

Blacconiere, Walter G. and Dennis M. Patten (1994), "Environmental Disclosures, Regulatory Costs, and Changes in Firm Value," Journal of Accounting and Economics, 18 (3), 149-78.

Bragdon, Joseph H. and John A.T. Marlin (1972), "Is Pollution Profitable?" Risk Management, 19 (4), 9-18.
Campbell, John L. (2007), "Why Would Corporations Behave in Socially Responsible Ways? An Institutional Theory of Corporate Social Responsibility," Academy of Management Review, 32 (3), 946-67.

Carroll, Archie B. (1979), "A Three-Dimensional Conceptual Model of Corporate Social Performance," Academy of Management Review, 4 (4), 497-505.

(1991), "The Pyramid of Corporate Social Responsibility: Toward the Moral Management of Organizational Stakeholders," Business Horizons, 34 (4), 39-48.

(1999), "Corporate Social Responsibility," Business and Society, 38 (3), 268-95.

Chen, Kung H. and Richard W. Metcalf (1980), "The Relationship Between Pollution Control Record and Financial Indicators Revisited," Accounting Review, 55 (1), 168-77.

Davidson, Wallace N. and Dan L. Worrell (1988), "The Impact of Announcements of Corporate Illegalities on Shareholder Returns," Academy of Management Journal, 31 (1), 195-200.

__ and (1992), "The Effect of Product Recall Announcements on Shareholder Wealth," Strategic Management Journal, 13 (6), 467-73.

Elkington, John (1994), "Towards the Sustainable Corporation: Win-Win-Win Business Strategies for Sustainable Development," California Management Review, 36 (2), 90-100.

(1998), Cannibals with Forks: The Triple Bottom Line of 21st Century Business. Gabriola Island, BC: New Society Publishers.

Forbus, Pamela (2007), talk given at the Stakeholder Marketing Consortium, Aspen, Colorado (September 15).

Frank, Robert (2007), Richistan: A Journey Through the American Wealth Boom and the Lives of the New Rich. New York: Crown Publishers.

Frederick, Shane, George Loewenstein, and Ted O'Donoghue (2002), "Time Discounting and Time Preference: A Critical Review," Journal of Economic Literature, 40 (2), 351-401.

Freedman, Martin and Bikki Jaggi (1982), “An Analysis of the Impact of Corporate Pollution Disclosures Included in Annual Financial Statements on Investors' Decisions," in Advances in Public Interest Accounting, Vol. 1, Marilyn Neimark, ed. Greenwich, CT: JAI Press, 193-212.

Friedman, Milton (1970), "The Social Responsibility of Business Is to Increase Its Profits," New York Times Magazine, (September 13), 32-33, 122, 124, 126.

Frooman, Jeff (1997), "Socially Irresponsible and Illegal Behavior and Shareholder Wealth: A Meta-Analysis of Event Studies," Business and Society, 36 (3), 221-49.

Goyal, Ashima (2006), "Corporate Social Responsibility as a Signaling Device for FDI," International Journal of the Economics of Business, 13 (1), 145-63.

Grossman, Blake R. and William F. Sharpe (1986), "Financial Implications of South African Divestment," Financial Analysts Journal, 42 (July-August), 15-29.

Hamilton, James T. (1995), "Pollution as News: Media and Stock Market Reactions to the Toxics Release Inventory Data," Journal of Environmental Economics and Management, 28 (1), 98-113.

Hamilton, Sally, Hoje Jo, and Meir Statman (1993), "Doing Well While Doing Good? The Investment Performance of Socially 
Responsible Mutual Funds," Financial Analyst Journal, 49 (6), 62-66.

Harjoto, Maretno A. and Hoje Jo (2007), "Corporate Governance and Firm Value: The Impact of Corporate Social Responsibility," working paper, Leavey School of Business, Santa Clara University.

Harper, Richard K. and Stephen C. Adams (1996), "CERCLA and Deep Pockets: Market Response to the Superfund Program," Contemporary Economic Policy, 14 (1), 107-115.

Hart, Stuart L. and Gautam Ahuja (1996), "Does It Pay to Be Green? An Empirical Examination of the Relationship Between Emission Reduction and Firm Performance," Business Strategy and the Environment, 5 (1), 30-37.

Hermalin, Benjamin E. (2005), "Trends in Corporate Governance," Journal of Finance, 60 (5), 2351-84.

Hill, Ronald P., Thomas Ainscough, Todd Shank, and Daryl Manullang (2007), "Corporate Social Responsibility and Socially Responsible Investing: A Global Perspective," Journal of Business Ethics, 70 (2), 165-74.

Ingram, Robert W. (1978), “An Investigation of the Information Content of (Certain) Social Responsibility Disclosures," Journal of Accounting Research, 16 (2), 270-85.

Jarrell, Gregg and Sam Peltzman (1985), “The Impact of Product Recalls on the Wealth of Sellers," Journal of Political Economy, 93 (3), 512-36.

Jensen, Michael (2002), "Value Maximization, Stakeholder Theory, and the Corporate Objective Function," Business Ethics Quarterly, 12 (2), 235-56.

Kanter, Rosabeth M. (1999), "From Spare Change to Real Change: The Social Sector as Beta Site for Business Innovation," Harvard Business Review, 77 (3), 123-32.

Karpoff, Jonathan M. and John R. Lott (1993), “The Reputational Penalty Firms Bear from Committing Criminal Fraud," Journal of Law and Economics, 36 (2), 757-802.

—, - and Eric W. Wehrly (2005), "The Reputational Penalties for Environmental Violations: Empirical Evidence," Journal of Law and Economics, 48 (2), 653-75.

Kelly, Marjorie (2004), "Holy Grail Found: Absolute, Definite Proof CSR Pays Off," Business Ethics, 18 (4), 4-5.

Kenton, Chris (2005), "What's Really Behind the Drive Toward Metrics," in Marketing Magnified, CMO Council, (accessed January 18, 2010), [available at http://www.marketingmagnified. com/2005/october/oct05.pdf].

Knack, Stephen and Philip Keefer (1997), "Does Social Capital Have an Economic Payoff? A Cross-Country Investigation," Quarterly Journal of Economics, 112 (4), 295-321.

Konar, Shameek and Mark Cohen (2001), "Does the Market Value Environmental Performance?" Review of Economics and Statistics, 83 (2), 281-89.

Kreander, Niklas, Rob H. Gray, David M. Power, and C.D. Sinclair (2005), "Evaluating the Performance of Ethical and NonEthical Funds: A Matched Pair Analysis," Journal of Business Finance \& Accounting, 32 (7-8), 1465-93.

Lemon, Katherine N. and Kathleen Seiders (2005), "Making Marketing Accountable: A Broader View," in Does Marketing Need Reform? J. Sheth and R. Sisodia, eds. Armonk, NY: M.E. Sharpe, 201-208.

Luck, Christopher and Nancy Pilotte (1993), "Domini Social Index Performance," Journal of Investing, 2 (Fall), 60-62.
Luo, Xueming and C.B. Bhattacharya (2006), "Corporate Social Responsibility, Customer Satisfaction, and Market Value," Journal of Marketing, 70 (October), 1-18.

Margolis, Joshua D., Hillary A. Elfenbein, and James P. Walsh (2007), "Does It Pay to Be Good? A Meta-Analysis and Redirection of Research on Corporate Social and Financial Performance," working paper, Haas School of Business, University of California at Berkeley.

and James P. Walsh (2003), "Misery Loves Companies: Rethinking Social Initiatives by Business," Administrative Science Quarterly, 48 (2), 268-305.

Marketing Science Institute (2008), 2008-2010 Research Priorities: A Guide to MSI Research Programs and Procedures. Cambridge, MA: Marketing Science Institute.

McWilliams, Abagail and Donald Siegel (2001), "Corporate Social Responsibility and Firm Financial Performance: Correlation or Misspecification?" Strategic Management Journal, 21 (5), 603-609.

Mick, David (2007), "The End(s) of Marketing and the Neglect of Moral Responsibility by the American Marketing Association," Journal of Public Policy \& Marketing, 26 (Fall), 289-92.

Moore, Geoffrey (1999), Crossing the Chasm: Marketing and Selling Technology Products to Mainstream Customers. New York: Capstone Publishing.

Morrissey, Daniel J. (1989), "Toward a New/Old Theory of Corporate Social Responsibility," Syracuse Law Review, 40, 1005-1039.

Nakao, Yuriko, Akihiro Amano, Kanichiro Matsumura, Kiminori Genba, and Makiko Nakano (2007), "Relationship Between Environmental Performance and Financial Performance: An Empirical Analysis of Japanese Corporations," Business Strategy and the Environment, 16 (2), 106-118.

Navarro, Peter (1988), "Why Do Corporations Give to Charity?" Journal of Business, 61 (1), 65-93.

Orlitzky, Marc, Frank L. Schmidt, and Sara L. Rynes (2003), "Corporate Social and Financial Performance: A Meta-Analysis," Organization Studies, 24 (3), 403-441.

Peloza, John (2006), “Using Corporate Social Responsibility as Insurance for Financial Performance," California Management Review, 48 (2), 52-72.

Ray, Debraj (1998), Development Economics. New York: Princeton University Press.

Rosenbloom, Jerry S. (2001), The Handbook of Employee Benefits, 5th ed. New York: McGraw-Hill.

Rust, Roland T., Katherine N. Lemon, and Valarie A. Zeithaml (2004), "Return on Marketing: Using Customer Equity to Focus Marketing Strategy," Journal of Marketing, 68 (January), 109-127.

Sandelands, Lloyd E. (2003), "The Argument for God from Organization Studies," Journal of Management Inquiry, 20 (10), $1-10$.

Sauer, David (1997), “The Impact of Social-Responsibility Screens on Investment Performance: Evidence from the Domini 400 Social Index and Domini Equity Mutual Fund," Review of Financial Economics, 6 (2), 137-49.

Schnietz, Karen E. and Marc J. Epstein (2005), "Exploring the Financial Value of a Reputation for Corporate Social Responsibility During a Crisis," Corporate Reputation Review, 7 (4), $327-45$. 
Schwartz, Robert (1968), "Corporate Philanthropic Contributions," Journal of Finance, 23 (3), 479-97.

Sen, Sankar and C.B. Bhattacharya (2001), "Does Doing Good Always Lead to Doing Better? Consumer Reactions to Corporate Social Responsibility," Journal of Marketing Research, 38 (May), 225-43.

—, , and Daniel Korschun (2006), "The Role of Corporate Social Responsibility in Strengthening Multiple Stakeholder Relationships: A Field Experiment," Journal of the Academy of Marketing Science, 34 (2), 158-66.

Shank, Todd, Daryl Manullang, and Ron Hill (2005), "Doing Well While Doing Good Revisited: A Study of Socially Responsible Firms' Short-Term Versus Long-Term Performance," Managerial Finance, 31 (8), 33-46.

Silten, Bobbi (2007), talk given at the Stakeholder Marketing Consortium, Aspen, Colorado (September 14).

Spar, Debora L. and Lane T. La Mure (2003), "The Power of Activism," Assessing the Impact of NGOs on Global Business, 45 (3) 78-101.
Srinivasan, Shuba and Dominique Hanssens (2009), "Marketing and Firm Value: Metrics, Methods, Findings, and Future Directions," Journal of Marketing Research, 36 (June), 293-312.

Statman, Meir (2000), "Socially Responsible Mutual Funds," Financial Analysts Journal, 56 (3), 30-39.

Strom, Stephanie (2007), "Rules Sought on Retailers' Ties to Charities," The New York Times, (December 16), (accessed January 18, 2010), [available at http://www.nytimes.com/2007/12/ 16/washington/16giving.html].

Van de Velde, Eveline, Wim Vermeir, and Filip Corten (2005), "Finance and Accounting: Corporate Social Responsibility and Financial Performance," Corporate Governance, 5 (3), 129-38.

Vershoor, Curtis C. (1998), "A Study of the Link Between a Corporation's Financial Performance and Its Commitment to Ethics," Journal of Business Ethics, 17 (13), 1509-1516.

Walsh, James P. (2005), "Taking Stock of Stakeholder Theory," Academy of Management Review, 30 (2), 426-38.

Wells, C.A. Harwell (2002), "The Cycles of Corporate Social Responsibility: An Historical Retrospective for the TwentyFirst Century," Kansas Law Review, 51 (November), 77-140. 